\title{
Non-herpetic acute limbic encephalitis
}

INSERM

\section{Source}

INSERM. (1999). Orphanet: an online rare disease and orphan drug data base. Nonherpetic acute limbic encephalitis. ORPHA:163924

Non-herpetic acute limbic encephalitis is a rare neuroinflammatory/neuroautoimmune disease characterized by an acute (or subacute) onset of disturbance of consciousness (occasionally presenting as convulsions) and high fever, associated with cerebral lesions (on magnetic resonance imaging) that are restricted to the limbic system (particularly the hippocampi and amygdalae), in the absence of viral, bacterial, fungal, paraneoplastic and other disorders. 